\title{
Obtaining iron and graphite nanoparticles in argon plasma ${ }^{(\bullet)}$
}

\author{
${\text { I. } \operatorname{Bica}^{(*)} \text { and I. Muscutari }}^{(*)}$

\begin{abstract}
The experimental equipment designed for obtaining iron and graphite nanoparticles in argon plasma, the building mechanisms of particles as well as the experimental results on $\mathrm{Fe}(\mathrm{CO})_{5}$ and .2-ethylhexyl-iron maleat dissociation by plasma jet are presented. The dimensions of the metal particles obtained range from 30 to $200 \AA$, while the graphite particles vary from 30 to $100 \AA$.
\end{abstract}

Keywords: Plasma. Iron. Graphite. Nanoparticles.

\section{Obtención de nanopartículas de hierro y de grafito en plasma de argón}

Resumen Se presenta el equipo experimental ideado para obtener partículas de hierro y de grafito en plasma de argón, así como los mecanismos de formación de dichas partículas y los resultados experimentales alcanzados mediante la disociación de $\mathrm{Fe}(\mathrm{CO})_{5}$ y maleato de 2-etil-hexil-hierro por el chorro de plasma. Las dimensiones de las partículas metálicas obtenidas varían entre 30 y $200 \AA$, mientras que las de grafito van de 30 a $100 \AA$.

Palabras clave: Plasma. Hierro. Grafito. Nanopartículas.

\section{INTRODUCTION}

Nanoparticles are a special category of particles. Their physical properties, and specially their time evolution (1), which are sensibly different from the material they originate from, make them interesting from the scientific point of view (2-4) as well as for some applications (5-9). That is why there is a special interest in obtaining nanoparticles (10-16).

An experimental capacitive plasma equipment for the thermal dissociation of a solution of toluene with $\mathrm{Fe}(\mathrm{CO})_{5}$ was proposed in (17). The nanoparticles obtained with this equipment were succesfully used for the preparation of magnetic fluid samples.

Iron and graphite nanoparticles could be obtained using argon plasma jets. The corresponding equipment and the experimental results are presented below.

(•) Trabajo recibido el día 27 de noviembre de 1995.

(*) Condensed Matter Research Institute. Str. Tirnava nr. 1, 1900, Timisoara (Romania).

\section{EXPERIMENTAL EQUIPMENT}

The equipment designed for obtaining nanoparticles in argon plasma is shown in figure 1 . The operation mode of the equipment is as follows.

The electric arc in the argon medium is started between the cathode $K$ and the anode $A$ of the plasma generator, employing a high frequency generator. The source $S$ supplies the electric arc at a preset, constant-in-time current. Under argon pressure, a jet of ionized gas streams out through the nozzle $A$ of the plasma generator, with the flow rate controlled by the $R 2$ flow controller.

A solution of $\mathrm{Fe}(\mathrm{CO})_{5}$ or 2-ethyl-hexyl-iron maleat is introduced through the tube $T l$ in the plasma jet. The carrier gas flow is adjusted by the flow controller $R 1$, while the gas/solution ratio is adjusted by the sprayer/doser 5 . The thermal dissociation reaction of $\mathrm{Fe}(\mathrm{CO})_{5}$ takes place in the plasma jet. The reaction elements condensate so that, for a given temperature, pressure and concentration phase, solid particles are formed.

The particles are drawn by the gas in the collecting liquid $M L 1$, which is thermostated and 


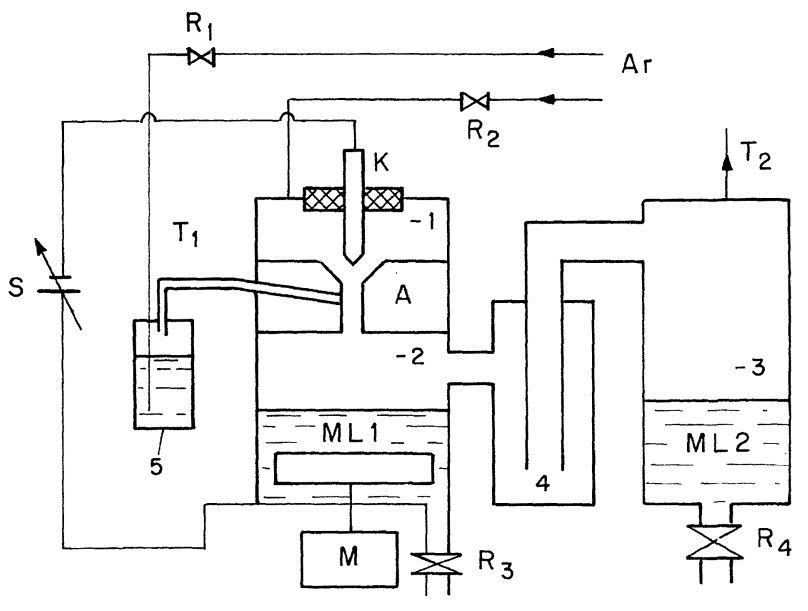

FIG. 1.- Experimental equipment (principal sketch). 1: Plasma generator. 2 and 3: Powder collecting chambers. 4: Heat exchanger. 5: sprayer/doser. S: power source.

FIG. 1.- Equipo experimental. 1: Generador de plasma. 2 y 3: Cámara de recogida de polvos. 4: Intercambiador de calor. 5: Pulverizador/ dosificador. S: Fuente de energía.

strongly stirred by the agitator $M$. The particles which remain in the carrier gas are driven through the water/gas heat exchanger 4 , and then into the collecting chamber 3 . The fine particle fraction is collected by the liquid $M L 2$.

The liquids $M L 1$ and $M L 2$ containing the nanoparticles are recovered through the taps $R 3$ and $R 4$. The residual gases are drawn out by the pipe $T 2$.

\section{THERMAL DISSOCIATION OF $\mathrm{Fe}(\mathrm{CO})_{5}$. EXPERIMENTAL RESULTS}

The speed, $\boldsymbol{v}_{\mathrm{j}}$, of the plasma jet, obtained with the plasma generator shown in figure 1 , has a linear dependence of the intensity, $I$, of the discharge current (Fig. 2). At speeds between 130 and $230 \mathrm{~m} / \mathrm{s}$, the flow is turbulent $\left(R_{\mathrm{e}}>>1\right)(18$ and 19$)$. The $\mathrm{Fe}(\mathrm{CO})_{5}$ solution drops introduced under argon pressure into the plasma jet have a speed of (18 and 19):

$$
v_{\mathrm{p}}=\frac{v_{\mathrm{j}} t}{t^{\prime}+t}
$$

and covers in $t$ time the distance:

$$
L=v_{\mathrm{j}}\left[t-t^{\prime} \ln \left(1+t / t^{\prime}\right)\right]
$$

The time $t^{\prime}(19)$ is obtained from the expression:

$$
t^{\prime}=\frac{4 d_{\mathrm{p}} v_{j}}{3 \psi v_{\mathrm{p}} \rho_{j}}
$$

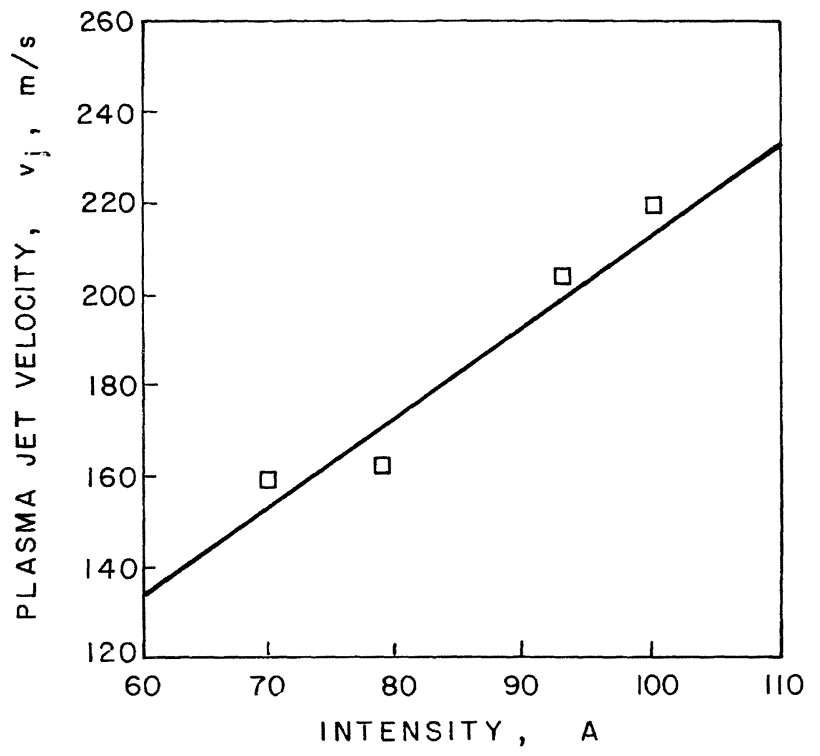

FIG. 2.- Speed of the argon plasma jet, $v_{\mathrm{j}}$, as a function of the intensity of the discharge current, $I$. (13) Argon flow: 25 litres/min; nozzled diameter, $4 \mathrm{~mm}$.

FIG. 2.- Velocidad del chorro de plasma de argón, $\mathrm{v}_{\mathrm{j}}$, en función de la intensidad de la corriente de descarga, I. (13) Flujo de argón: 25 litros/min; diámetro de la boquilla, $4 \mathrm{~mm}$.

where:

$d_{\mathrm{p}}=$ drop diameter

$v_{\mathrm{j}}=$ plasma kinematic viscosity coefficient

$\psi=$ plasma drag coefficient related to the motion of the particle

$\rho_{\mathrm{j}}=$ plasma density

During $t$ time, the $\mathrm{Fe}(\mathrm{CO})_{5}$ solution drop in the plasma jet will have the temperature (18):

$$
T_{\mathrm{p}}=T_{\mathrm{j}}-\left(T_{\mathrm{j}}-T_{\mathrm{p} 0}\right) \exp \left[-\frac{6 \lambda t}{c_{\mathrm{p}} \rho_{\mathrm{p}} d_{\mathrm{p}}}\right]
$$

Here

$T_{\mathrm{j}} \quad=$ plasma jet temperature

$T_{\mathrm{p} 0}=$ initial drop temperature

$C_{\mathrm{p}}=$ specific heat of the drop

$\lambda=$ thermal convection coefficient

The $\mathrm{Fe}(\mathrm{CO})_{5}$ solution drop diameter, $d_{\mathrm{p}}$, is estimated to be in the range $0.1-1 \mu \mathrm{m}$. For $(20), v_{\mathrm{j}}$ $=3.4 \cdot 10^{-3} \mathrm{~m} / \mathrm{s}, \rho_{\mathrm{p}}=6.5 \cdot 10^{3} \mathrm{~kg} \cdot \mathrm{m}^{-3}, \Psi=6.66$ and, respectively, for $v_{\mathrm{j}}=132 \mathrm{~m} / \mathrm{s}$ (Fig. 2) (3) yields $t^{\prime}=$ $86 \cdot 10^{-12} \mathrm{~s}$.

Considering that $t^{\prime}>t$, eq. [1] yields $v_{\mathrm{p}} \approx v_{\mathrm{j}}$. From [2], it can be seen that $L$ is approximately equal to the length of the plasma jet.

The plasma temperature, $T_{\mathrm{j}}$, decreases linearly along the length $l$ of the argon plasma jet (13) (Fig. 3). 


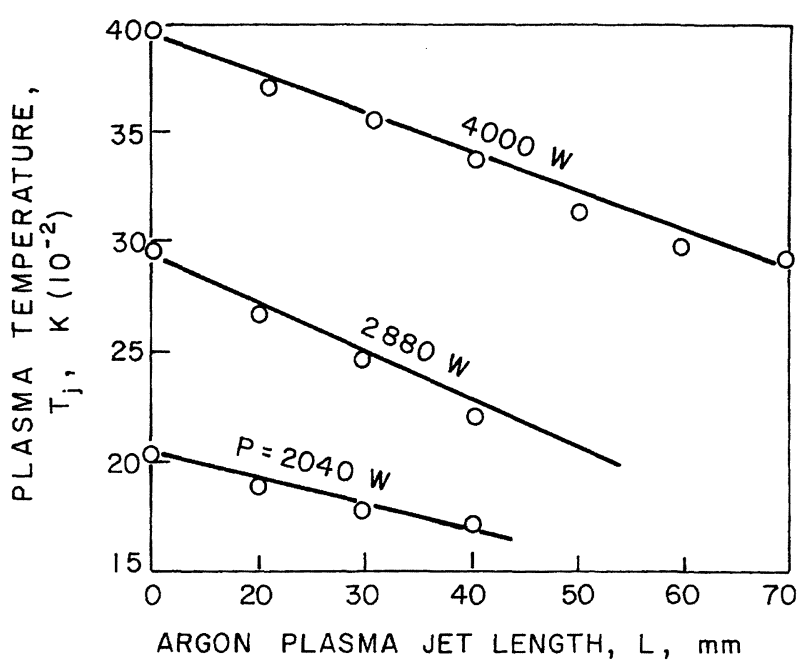

FIG. 3.- Temperature along the argon plasma jet length for different powers of the electric discharge (13).

FIG. 3.- Temperatura en toda la longitud del chorro de plasma de argón para diferentes potencias de la descarga eléctrica (13).

For $\lambda=8.36 \mathrm{~J} \cdot \mathrm{m}^{-2} \cdot \mathrm{s}^{-1} \cdot \mathrm{K}^{-1}(18)$ and $c_{\mathrm{p}}=5 \cdot 10^{-4}$ $\mathrm{J} /(\mathrm{mol} \cdot \mathrm{K})(20)$, eq. [4] yields $T_{\mathrm{p}} \approx T_{\mathrm{j}}$.

At temperatures $T_{\mathrm{j}} \approx 1,700 \mathrm{~K}$, the thermal dissociation of $\mathrm{Fe}(\mathrm{CO})_{5}$ takes place (13 and 21) as follows:

$$
\mathrm{Fe}(\mathrm{CO})_{5} \Leftrightarrow \mathrm{Fe}+5 \mathrm{CO}
$$

which is followed by possible secondary reactions:

$$
\begin{aligned}
& \mathrm{CO} \Leftrightarrow 0.5 \mathrm{CO}_{2}+0.5 \mathrm{CO} \\
& 0.75 \mathrm{Fe}+\mathrm{CO} \Leftrightarrow 0.25 \mathrm{Fe}_{3} \mathrm{O}_{4}+\mathrm{C} \\
& 0.75 \mathrm{Fe}+\mathrm{CO} \Leftrightarrow 0.25 \mathrm{Fe}_{3} \mathrm{O}_{4}+\mathrm{Fe}_{3} \mathrm{C} \\
& 1.5 \mathrm{Fe}+\mathrm{CO} \Leftrightarrow 0.5 \mathrm{Fe}_{3} \mathrm{C}+0,5 \mathrm{CO}_{2} \\
& 1.5 \mathrm{Fe}+\mathrm{CO}_{2} \Leftrightarrow 0.5 \mathrm{Fe}_{3} \mathrm{O}_{4}+\mathrm{Fe}_{3} \mathrm{C} \\
& 0.166 \mathrm{Fe}_{3} \mathrm{O}_{4}+\mathrm{CO} \Leftrightarrow 0.166 \mathrm{Fe}_{3} \mathrm{C}+0.83 \mathrm{CO}_{2} \\
& 0.25 \mathrm{Fe}_{3} \mathrm{O}_{4}+\mathrm{CO} \Leftrightarrow 0.75 \mathrm{Fe}_{3}+\mathrm{CO}_{2} \\
& 0.25 \mathrm{Fe}_{3} \mathrm{O}_{4}+\mathrm{CO} \Leftrightarrow 0.25 \mathrm{Fe}_{3} \mathrm{O}_{4}+1.25 \mathrm{C}
\end{aligned}
$$

The thermal dissociation of $\mathrm{Fe}(\mathrm{CO})_{5}$ is influenced by the temperature, $T_{\mathrm{j}}$, and by the carbon monoxide pressure, $p_{\mathrm{CO}}(21)$, respectively (Fig. 4). At temperatures $T_{\mathrm{j} 0}=2,000 \mathrm{~K}$ (Fig. 3), the particles resulting as a consequence of the thermal dissociation of $\mathrm{Fe}(\mathrm{CO})_{5}$ constitute a heterophased system with cobalt pentacarbonile solution. At temperatures $T_{\mathrm{j} 1}=(1 / 3) T_{\mathrm{j} 0}$, the activating energy for the crystal nucleus formation becomes maximal (22). The formed nucleus becomes stable when it contains at least a critical number of atoms (22). The growth of any crystal nucleus is due to atom deposition on its surface. The nucleus growing speed becomes maximal when the system

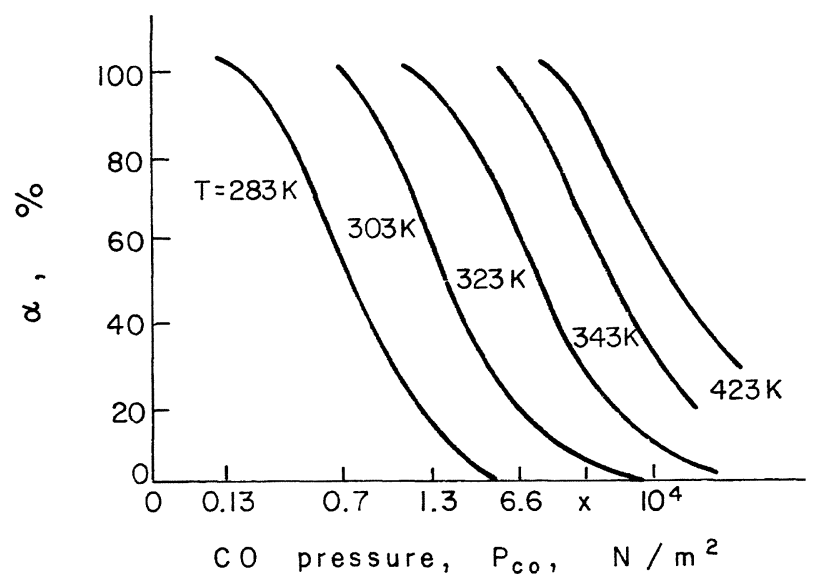

FIG. 4. $-\alpha$ dissociation degree of $\mathrm{Fe}(\mathrm{CO})_{5}$ as a function of the pressure of carbon monoxide for different temperatures, $T_{\mathrm{j}}$.

FIG. 4.- Grado de disociación a del $\mathrm{Fe}(\mathrm{CO})_{5}$ en función de la presión del monóxido de carbono para diferentes temperaturas, $\mathrm{T}_{\mathrm{j}}$.

temperature, $T_{\mathrm{j} 2}$, is equal to half the optimal germination temperature, $T_{\mathrm{j} 1}(22)$, that is:

$$
T_{\mathrm{j} 2}=0,5 T_{\mathrm{j} 1}
$$

The optimal technological conditions which were found experimentally are presented in table I. The particles (Fig. 5) have been collected in dodecylbenzene with thermostated $15 \%$ sodium di2-ethylsulphosuccinate at $423 \mathrm{~K} \pm 20 \%$ (13). The pressure in the powder collecting chamber has been kept about $1.1 \cdot 10^{5} \mathrm{~N} / \mathrm{m}^{2}$.

Nanoparticles size is in the range $30-200 \AA$, with an average diameter, $D=121 \pm 6 \AA$ (Fig. 6).

Mössbauer spectroscopic analysis of the achieved material, performed at the IFTM Bucharest showed the existence of $26.5 \%$ of paramagnetic iron particles, $18 \%$ of supermagnetic particles (which are not ordered at $70 \mathrm{~K}$ ) and 55.5 $\%$ of iron carbide, repsectively.

Cooling speeds of $4,050 \mathrm{~K} /(\mathrm{ms})$ only for about $25 \%$ of the metal particles created at plasma level,

TABLE I.- Optimal technological conditions found experimentally

TABLA I.- Condiciones tecnológicas óptimas determinadas experimentalmente

\begin{tabular}{|cccccc|}
\hline$I$, & $U$, & $P$, & $D_{1}$, & $D_{2}$, & $D_{3}$, \\
$\mathrm{A}$ & $\mathrm{V}$ & $\mathrm{W}$ & $1 / \mathrm{min}$ & $1 / \mathrm{min}$ & $1 / \mathrm{min}$ \\
\hline 60 & 34 & 2,040 & 15 & 20 & 0.75 \\
\hline
\end{tabular}

$D_{1}=$ flujo de argón

$D_{2}=$ flujo del gas portador (argón)

$D_{3}=$ flujo de la solución de $\mathrm{Fe}(\mathrm{CO})_{5}$ 


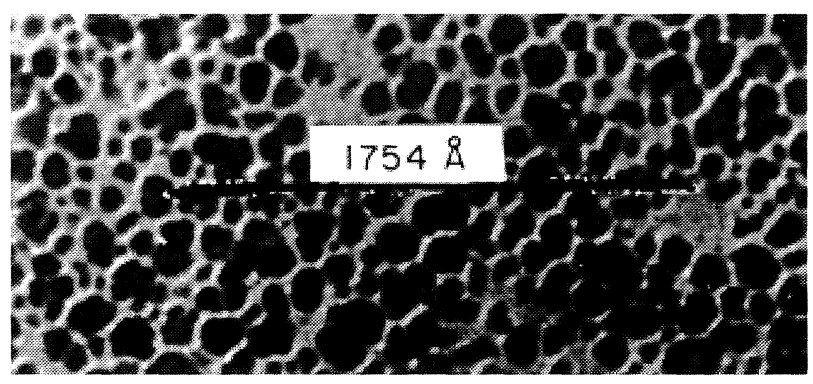

FIG. 5.- Metal particles obtained in the plasma jet.

FIG. 5.- Partículas metálicas obtenidas en el chorro de plasma.

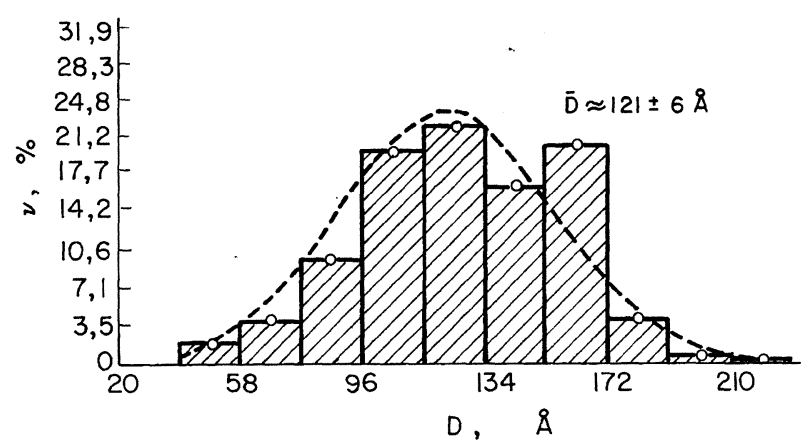

FIG. 6.- Dimensional distribution of the metal nanoparticles.

FIG. 6.-Distribución dimensional de las nanopartículas metálicas.

were found to produce an amorphous material. Due to the existence of a notable amount of $\mathrm{CO}$, there is no iron particle carburation during the thermal dissociation of $\mathrm{Fe}(\mathrm{CO})_{5}$.

It is possible to reduce the iron carbide quantity by creating a connection between the $3 d$ free orbitals of iron and nitrogen atoms. This is possible by using mixed plasmagenous gas $\left(\mathrm{Ar}+\mathrm{NH}_{3}\right)$.

\section{OBTAINING GRAPHITE NANOPARTICLES. EXPERIMENTAL RESULTS}

The temperatures obtained in argon plasma jets (Fig. 3) (13) initiate the thermal dissociation of 2ethyl-hexyl-iron maleat jet sprayed in argon:

$$
\left.\mathrm{Fe}+\mathrm{OOC}-\mathrm{CH}=\mathrm{CH}-\mathrm{COO}-\left(\mathrm{CH}_{2}\right)_{4}-\underset{\mathrm{C}_{2} \mathrm{H}_{5}}{\mathrm{CH}}-\mathrm{CH}_{3}\right] \rightarrow
$$

Nanoparticles were obtained at a flow rate of 2 $\mathrm{ml} / \mathrm{min}$ of 2-ethyl-hexyl-iron maleat at plasma jet parameters corresponding to data shown in figure 7 .

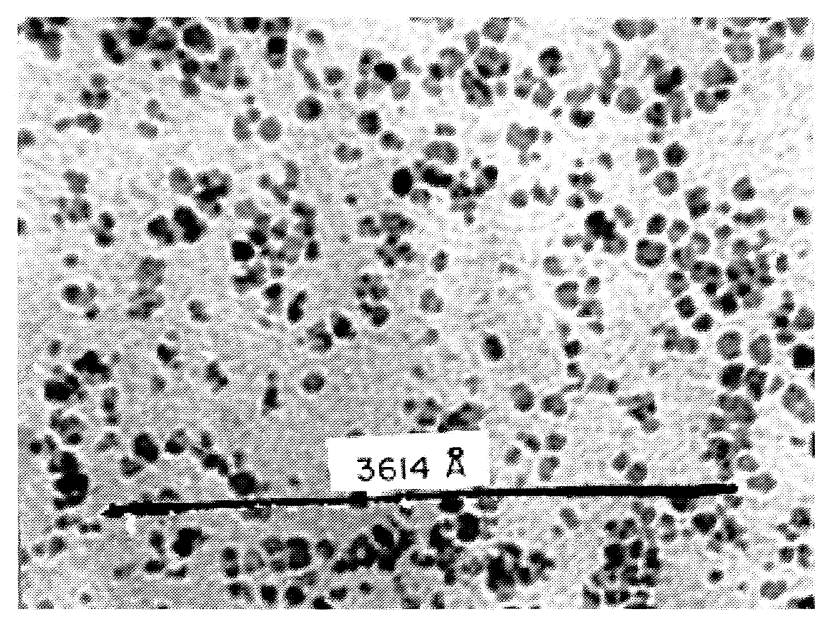

FIG. 7.- Graphite particles obtained in the plasma jet. $(\times 207,500)$.

FIG. 7.- Partículas de grafito obtenidas en el chorro de plasma. $(\times 207.500)$.

The granulation of the obtained particles is between 30 and $100 \AA$, with an average of $63 \AA$ (Fig. 8). Dimensional control of nanoparticles using the 2ethyl-hexyl-iron maleat is done by means of the quantity introduced in argon plasma (22). So, at a 2-ethyl-hexyl-iron maleat flow rate of $6 \mathrm{ml} / \mathrm{min}$, particle granulation increased by about $80 \%$, comparing to that presented in figure 7 .

The obtained powder is collected in 2-ethylhexyl-sodium-sulphosuccinate. The temperature of the collecting liquid is maintained at $353 \mathrm{~K} \pm 20 \%$.

The iron in 2-ethyl-hexyl-iron maleat in a mass ratio of $1 / 5$ is transformed into ultrafine particles.

At pressures of $3 \cdot 10^{5} \mathrm{~N} / \mathrm{m}^{2}$, a part of the ultrafine iron particles is deposited on the walls of the powder collecting chamber while another part is drawn by residual passes toward the exterior. The cooling speed of $160,000 \mathrm{~K} / \mathrm{s}$ obtained in the plasma jet makes it possible to obtain not only

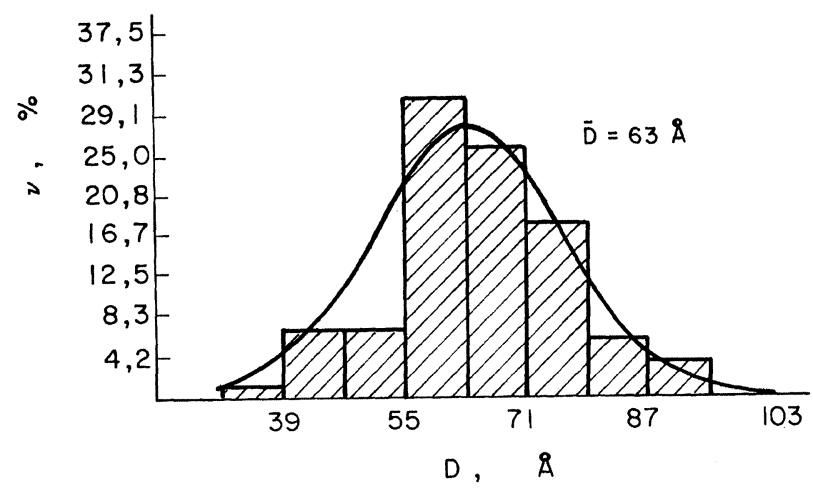

FIG. 8.- Histogram of the graphite particles.

FIG. 8.- Histograma de las partículas de grafito. 


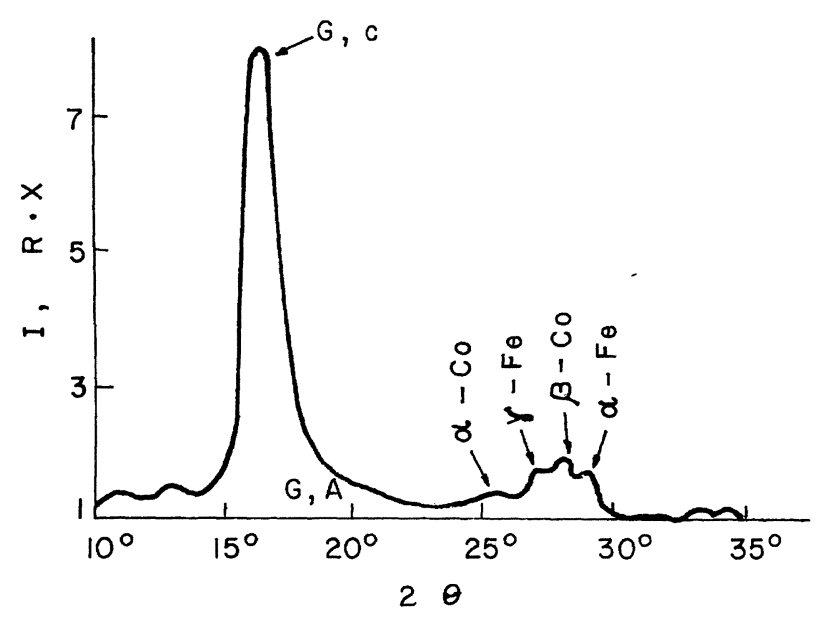

FIG. 9.- Röntgenogram of the graphite particles.

FIG. 9.- Röntgenograma de las partículas de grafito.

crystal graphite (G.C.) but amorphous graphite (G.A.) (Fig. 9).

\section{CONCLUSIONS}

Through monitoring pressure, temperature and concentration of $\mathrm{Fe}(\mathrm{CO})_{5}$ or 2-ethyl-hexyl-iron maleat both the nucleation and the particle growing conditions are estabilised. The dimensional control of the particles is performed from material flow rate introduced to plasma jet. Besides crystalline graphite, also amorphous graphite was obtained at a cooling rate of $16 \cdot 10^{4} \mathrm{~K} / \mathrm{s}$.

\section{REFERENCES}

(1) Blakemore, R. and O'Brien, K. Biochim. Biophys Acta., 11, 1983: 202.
(2) Gangopadnayoy, S. et al. Nano Structured Mater., 1, 1992: 77-81.

(3) Linderoth, S. et al. J. Magn. Magn. Mater., 124, 1993: 269-276.

(4) Kishisato, M. et al. IEEE Trans. Magn., 27, 1991: 4.6454.647.

(5) Lamge, F.F. J. Am. Ceram. Soc., 72, 1989: 3-15.

(6) BICA, D. and BICA, I. Preparation of magnetic fluids (in romanian) Physics Monographs 12. Univ. of Timisoara, 1992.

(7) Pmovenzano, V. et al. Nano Structured Mater., 1, 1992: 89-94.

(8) Shull, R.O. and BENNET, L.N. Nano Structured Mater., 1, 1992: 83-88.

(9) Gleiter, H. Nano Structured Mater., 1, 1992: 1-19.

(10) Inoue, A. et al. Metall. Trans., 19A, 1988: 2.315-2.318.

(11) UdA, M. et al. Nano Structured Mater., 1, 1992: 203-206.

(12) UDA, M. Nano Structured Mater., 1, 1992: 101-106.

(13) BICA, I. Doctoral Thesis. Univ. of Timisoara. 1991.

(14) BICA, I. VI Intern. Conf. Magn. Fluids. Book of Abstracts. Paris, 1992: 230-231.

(15) BICA, I. and BICA, D. Magnetohydrodynamics (Riga), 1, 1994: 121-122.

(16) Ziolo, R.F. et al. Science., 257, 1992: 219-223.

(17) NaKatami, J. J. Magn. Magn. Mater., 85, 1990: 11-13.

(18) Rykalin, N.N. Pure Appl. Chem., 48, 1976: 179-194.

(19) Rykalin, N.N. and Hudinov, V.V. Pure Appl. Chem., 48, 1976: 229-239.

(20) Lancaster, J.L. The Physics of Welding. Pergamon Press. Oxford, 1984.

(21) SARKIN, V.G: Himie i technologiie karbonilmih materialov. Izdatelstro HIMIIA. Moskow, 1972: 128.

(22) BICA I. Mechanisms of formation of graphite nanoparticles in argon plasma (to be published). 